\title{
Distribusi dan Pemetaan Cerita Rakyat Sasak pada Penutur Bahasa Sasak di Lombok
}

\author{
Rachmat Hidayat ${ }^{*}$
}

\begin{abstract}
Abstrak
Etnis sasak mengenal istilah wewaran atau cerita rakyat. Cerita rakyat ini tersebar di pulau Lombok. Masing-masing daerah penelitian memiliki cerita rakyat menarik yang diklafikasikan menurut kepercayaan masyarakat setempat dan dipetakan sebagai identitas keberadaan karya sastra Sasak.
\end{abstract}

Kata Kunci: legenda, mite, dongeng

\section{Pendahuluan}

Etnik Sasak merupakan etnik terbesar yang hampir menguasai 90\% pulau Lombok dari etnik yang lain. Etnik Sasak mempunyai empat dialek yang tersebar di pulau Lombok, yaitu dialek a-a, dialek a-e, dialek e-e, dan dialek a-o (Mahsun, 2015). Selain mempunyai aneka ragam dialek tersebut, etnik Sasak mempunyai kebudayaan tersendiri. Salah satu kebudayaan yang masih hidup sampai sekarang adalah seni sastra.

Di dunia sastra, dikenal adanya bentuk sastra lisan dan tulis. Istilah sastra lisan dalam masyarakat Indonesia diambil dari bahasa Inggris Oral Literature dan dari bahasa Belanda Oral Latterkude. Kedua istilah ini menunjukan ada pengertian tulisan atau buku (Welek dan Teeuw) dalam Hutorno (1991:1). Selanjutnya, yang disebut dengan sastra lisan adalah kesastraan yang mencakup ekspresi kesastraan warga suatu kebudayaan yang disebarkan dan diturun-temurunkan secara lisan (Hutomo, 1991:1)

Sastra lisan yang bersifat lisan dan diwariskan secara lisan dari generasi ke generasi pada etnik Sasak di pulau Lombok seperti, wewaran (dongeng/legenda/mite) pada masyarakat Sasak dalam waktu cepat atau lambat akan mulai dilupakan, atau bahkan bisa punah. Sastra lisan ada kalanya berkaitan dengan sastra tulis. Sebaliknya, sastra tulis kadangkadang menimba bahan dari sastra tulis. Oleh karena itu, tidak salah kiranya jika ada pendapat mengatakan bahwa antara ilmu sastra, sastra lisan dan tulis tidak perlu dibedakan secara tajam. Pendapat ini kiranya dapat dibuktikan pada cerita rakyat Sasak. Cerita rakyat yang diturunkan oleh masyarakat atau tukang cerita sebagian dituturkan secara lisan dan sebagian lagi diperoleh melaui naskah-naskah lontar yang masih ada ditengah-tengah masyarakat. 
Cerita rakyat pada umumnya memuat tentang hal-hal yang berhubungan dengan kepercayaan, keberanian, kepahlawanan, kepandaian, dan kepatuhan yang ingin ditanamkan dalam pribadi masa lampau. Cerita-cerita tersebut bukan semata pengantar tidur, melainkan juga sebagai salah satu proses pendididkan, pembentukan watak, dan kepribadian seseorang di lingkungan keluarga pada khususnya. Dengan bercerita, terciptalah hubungan komunikatif antara si pendengar dan si pencerita. Cerita rakyat sebagai salah satu unsur budaya daerah memiliki manfaat yang cukup banyak. Untuk itu, perlu pelestarian yang optimal.

\subsection{Masalah}

Sehubungan dengan latar belakang di atas, permasalahan yang akan dijawab dalam penelitian ini adalah sebagai berikut.

1. Bentuk dan jenis cerita rakyat apa saja yang ada pada masyarakat penutur bahasa Sasak.

2. Di manakah sebaran geografis masing-masing cerita rakyat tersebut?

3. Bagaimanakah deskripsi kondisi masyarakat pendukung rakyat tersebut?

\subsection{Tujuan}

Penelitian ini memberikan informasi, inventariasi tentang deskripsi bentuk, jenis-jenis cerita rakyat yang tumbuh dan berkembangtif pada masyarakat penutur bahasa Sasak di Lombok sehingga pengetahuan mengenai data itu dapat ditempuh dengan pemetaan sastra dan kebijakan dalam usaha membina dan mengembangkan sastra Indonesia.

\subsection{Landasan Teori}

Secara garis besar, karya sastra dibagi menjadi sastra lisan dan secara tulis. Dananjaya (1991:22) menyatakan bahwa jenis folktor lisan indonesia antara lain adalah a) bahasa rakyat, b) ungkapan tradisional, c) pertanyaan tradisional, d) sajak dan puisi rakyat, e) cerita prosa rakyat, dan f) nyanyian rakyat. Dari keenam jenis di atas, diambil satu jenis yang sesuai dengan penelitian ini. Dengan begitu, penelitian sastra untuk penelitian bentuk dan jenis cerita rakyat yang tumbuh dan berkembang dalam masyarakat penutur bahasa Sasak di Lombok yang penulis amdil yaitu cerita rakyat.

Menurut William R. Bascom (dalam Danan Jaya, 1991: 50), cerita rakyat dapat dibagi dalam tiga golongan besar, yaitu 1) mite (myth), 2) legenda (legends), dan 3) dongeng (folktale).

Mite adalah cerita yang dianggap benar-benar terjadi serta dianggap suci oleh yang mempunyai cerita. Mite ditokohi oleh para dewa atau mahluk setengah dewa. Peristiwanya biasanya terjadi di dunia lain atau di dunia yang bukan seperti yang kita sekarang; dan terjadi pada masa lampau. Mite pada umumnya mengisahkan terjadinya alam semesta, dunia, 
manusia pertama, terjadinya maut, berbentuk khas binatang, bentuk topografi, gejala alam, dan sebaganya. Mite juga mengisahkan petualngan para dewa, kisah percintaan, hubungan dan kekerabatan meraka, kisah perang, dan sebagainya.

Legenda adalah prosa rakyat yang mempunyai ciri-ciri yang mirip dengan mite, yaitu dianggap benar-benar terjadi, tetapi tidak dianggap suci. Legenda ditokohi oleh manusia biasa, walaupun kadang kala mempunyai sifat-sifat luar biasa; dan sering juga dibantu oleh mahluk ajaib.Tempat terjadinya peristiwa adalah di dunia seperti yang kita kenal dan waktu terjadinya belum terlalu lampau.

\section{Pembahasan}

\subsection{Populasi dan Sampel}

Populasi pada penelitian ini adalah bentuk dan jenis cerita rakyat yang tumbuh dan berkembang pada masyarakat tutur bahasa Sasak di pulau Lombok. Sampel pada penelitian ini adalah bentuk dan jenis cerita rakrat yang ada di wilayah penutur bahasa Sasak dialek a-a di Desa Bayan, Kabupaten Lombok Barat; dialek a-e di Desa Kawo, Kabuoaten Lombok Tengah; dialek e-e di desa Selaparang, Kabupaten Lombok Timur; dan dialek a-o di Desa Aibukaq, Kabupaten Lombok Tengah.

\subsection{Sumber Data}

Data yang dipergunakan dalam penelitian terdiri atas data primer dan data Sekunder.Data primer adalah data yang diambil sewaktu berada di lapangan atau masyarakat yaitu saat berlangsung penampilan dan wawancara dengan pelaku aktif. Data sekunder adalah data yang diambil dari perpustakaan dan museum, yaitu dari buku-buku tentang kebudayaan Sasak.

\subsection{Metode Pengumpulan Data}

Pengumpulan data dalam penelitian ini melalui beberapa tahapan. Teknik pengumpulan data anatara lain: observsi, wawancara, dan dokumentasi,

\subsection{Metode Analisis Data}

Langkah-Langkah analisis dalam pengelolan data yang dilakukan dalam penelitian ini dalah sebagai berikut.

1) Data rekaman dideskripkan atau dipindahkan dari bentuk rekaman ke bentuk tulisan. Kegiatan pentranskripsian dilakukan segera setalah perekaman data untuk memperkecilkan kemungkinan salah dengan transkripsi yang berupa karya sastra 
dipisahkan dari transkripsi wawancara dengan informan-informan seperti audiens dan tokoh-tokoh yang lain.

2) Karya Sastra yang telah ditranskripsikan diterjemahkan dalam bahasa Indonesia untuk memudahkan pemahaman pembaca. Penterjemahan dilakukan secara terikat untuk mengubah struktur asli karya.

3) Data-data yang telah ditranskripsikan dan terjemakan, kemudian dianalisis secara deskriptif dan diklasifikasikan untuk menentukan jenis dan betuk karya-karya sastra tersebut. Pengklasifikasian ini dilakukan dengan berpedoman pada konsep-konsep yang telah diuraikan.

4) Hasil dan pengklasifikasian dituangkan dalam bentuk tabulasi untuk memudahkan pengolongan jenis cerita rakyat.

\subsection{Sastra Lisan Berbentuk Cerita Rakyat}

Di kalangan masyarakat Sasak, terutama di kalangan kaum tua dan di kalangan anakanak, sastra lisan berbentuk cerita prosa rakyat atau disebut juga dengan cerita rakyak bahasa Sasak disebut dengan istilah wewaran, tampak hidup di saat ini. Sastra lisan berbebtuk prosa rakyat pada umumnya bersifat didaktis. Oleh karena itu, cerita rakyat dapat dijadikan sarana pendidikan oleh kaum tua terhadap anak-anaknya. Di samping itu, Sastra lisan berbentuk cerita rakyat dijadikan bahan penghiburan dan untuk mengantarkan anak tidur. Oleh karena itu, saat penyimpanannya biasanya dilakukan pada waktu malam hari menjelang saat anak-anak tidur disampaikan secara umum. Berdasarkan isinya, sastra lisan, cerita prosa rakyat dapat menjadi tiga, yaitu 1) mite (myth), 2) legenda (legend), dan 3) dongeng (folktale). Pada cerita rakyat ini, penulis menemukan 19 cerita rakyat yang tersebar pada empat sampel desa.

\subsubsection{Cerita Rakyat Desa Bayan}

Di Desa Bayan, ditemukan dua cerita rakyat yang berjudul 'Bibi Cili ' dan 'Cupak Gerantang'. Berdasarkan jenisnya, cerita rakyat ini adalah legenda. Pada cerita rakyat berjudul 'Cupak Gerantang', menutut informasi, cerita ini pernah dipentaskan pada suatu acara desa. Cerita rakyat ini dapat dilihat pada tabulasi berikut ini

\begin{tabular}{|c|c|c|c|c|c|c|c|c|c|}
\hline No. & Judul & Bentuk & Waktu & Setting & Tokoh & Alur & Dipercaya & Sifat & Jenis \\
\hline 1 & Bibi Cili & prosa & dahulu & $\begin{array}{l}\text { Dunia } \\
\text { seperti } \\
\text { sekarang } \\
\text { (zaman } \\
\text { kerajaan } \\
\text { keeling) }\end{array}$ & $\begin{array}{l}\text { Manusia } \\
\text { (Putri } \\
\text { Daha) }\end{array}$ & maju & fakta & Sekuler & legenda \\
\hline 2 & $\begin{array}{l}\text { Cupak } \\
\text { Gerantang }\end{array}$ & prosa & dahulu & $\begin{array}{l}\text { Dunia } \\
\text { seperti }\end{array}$ & $\begin{array}{l}\text { Manusia } \\
\text { (Cupak }\end{array}$ & maju & fakta & sekuler & legenda \\
\hline
\end{tabular}


Mabasan, Vol. 1, No. 2, Juli-Desember 2007: 49-62

\begin{tabular}{|l|l|l|l|l|l|l|l|l|}
\hline & & & $\begin{array}{l}\text { sekarang } \\
\text { (Zaman } \\
\text { kerajaan } \\
\text { Daha) }\end{array}$ & & & & \\
\hline
\end{tabular}


Peta 1

Sebaran Cerita Rakyat Desa Bayan

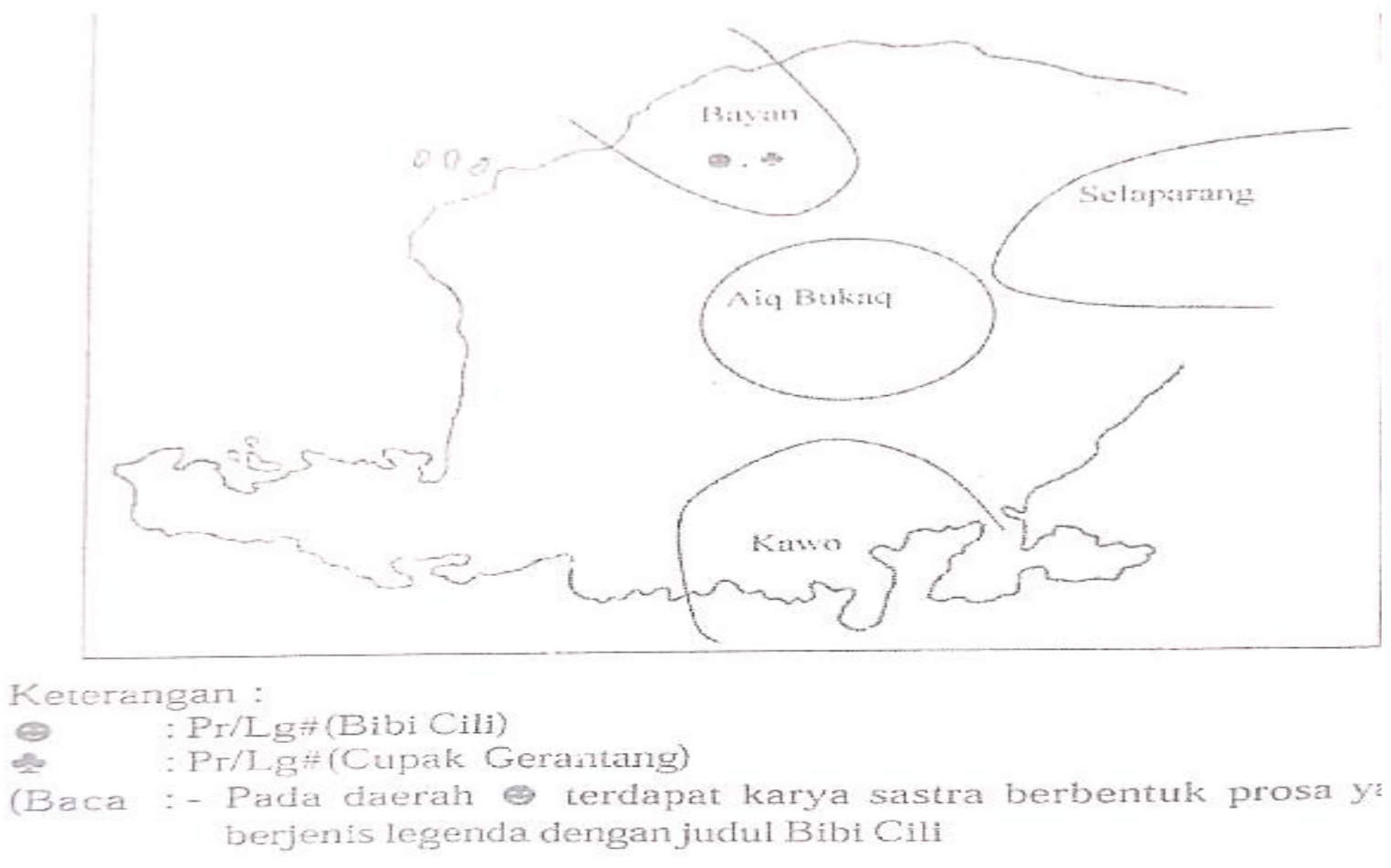

Scanned by CamScanner

- Pada daerah diatas terdapat karya sastra berbentuk prosa yang berjenis legenda dengan judul Cupak Gerantang).

\subsubsection{Cerita Rakyat Desa Aiq Bukaq}

Di desa aiq bukaq, ditemukan tiga cerita rakyat berjudul 'Raja Muhamad', 'Sesigar', 'Batu Golok', 'Tuak Tuntel-Untel (Kodok) dan 'Tuaq Tegodek (Kera)'. Berdasarkan jenisnya, cerita rakyat berjudul 'Raja Muhamad', 'Sesigar', 'Batu Golok', 'Tuak TuntelUntel (Kodok) dan 'Tuaq Tegodek (Kera)' adalah dongeng. Cerita Rakyat berjudul 'Batu Golok' berdasarkan jenisnya adalah legenda. 
Tabel 2

Tabulasi Cerita Rakyat Desa Aiq Bukaq

\begin{tabular}{|c|c|c|c|c|c|c|c|c|c|}
\hline No. & Judul & Bentuk & Waktu & Setting & Tokoh & Alur & Dipercaya & Sifat & Jenis \\
\hline 1 & $\begin{array}{l}\text { Raja } \\
\text { Muhamad }\end{array}$ & Prosa & Dahulu & $\begin{array}{l}\text { Dunia } \\
\text { Seperti } \\
\text { Sekarang } \\
\text { (Zaman } \\
\text { Kerajaan) }\end{array}$ & $\begin{array}{l}\text { Manusia } \\
\text { (Muhamad) }\end{array}$ & Maju & Fiksi & Religi & Dongeng \\
\hline 2 & Sesigar & Prosa & Dahulu & $\begin{array}{l}\text { Dunia } \\
\text { seperti } \\
\text { sekarang }\end{array}$ & $\begin{array}{l}\text { Manusia } \\
\text { (Sesigar) }\end{array}$ & Maju & Fiksi & Religi & Dongeng \\
\hline 3 & $\begin{array}{l}\text { Tuak } \\
\text { Tuntel } \\
\text { Dait Tuak } \\
\text { Tegodek }\end{array}$ & Prosa & & $\begin{array}{l}\text { Dunia } \\
\text { seperti } \\
\text { sekarang }\end{array}$ & $\begin{array}{l}\text { Hewan, } \\
\text { Manusia } \\
\text { (Tuntel, } \\
\text { Tegodek, } \\
\text { Hulubalang) }\end{array}$ & & & & \\
\hline
\end{tabular}

Peta 2

\section{Sebaran Cerita Rakyat Desa Aiq Bukaq}

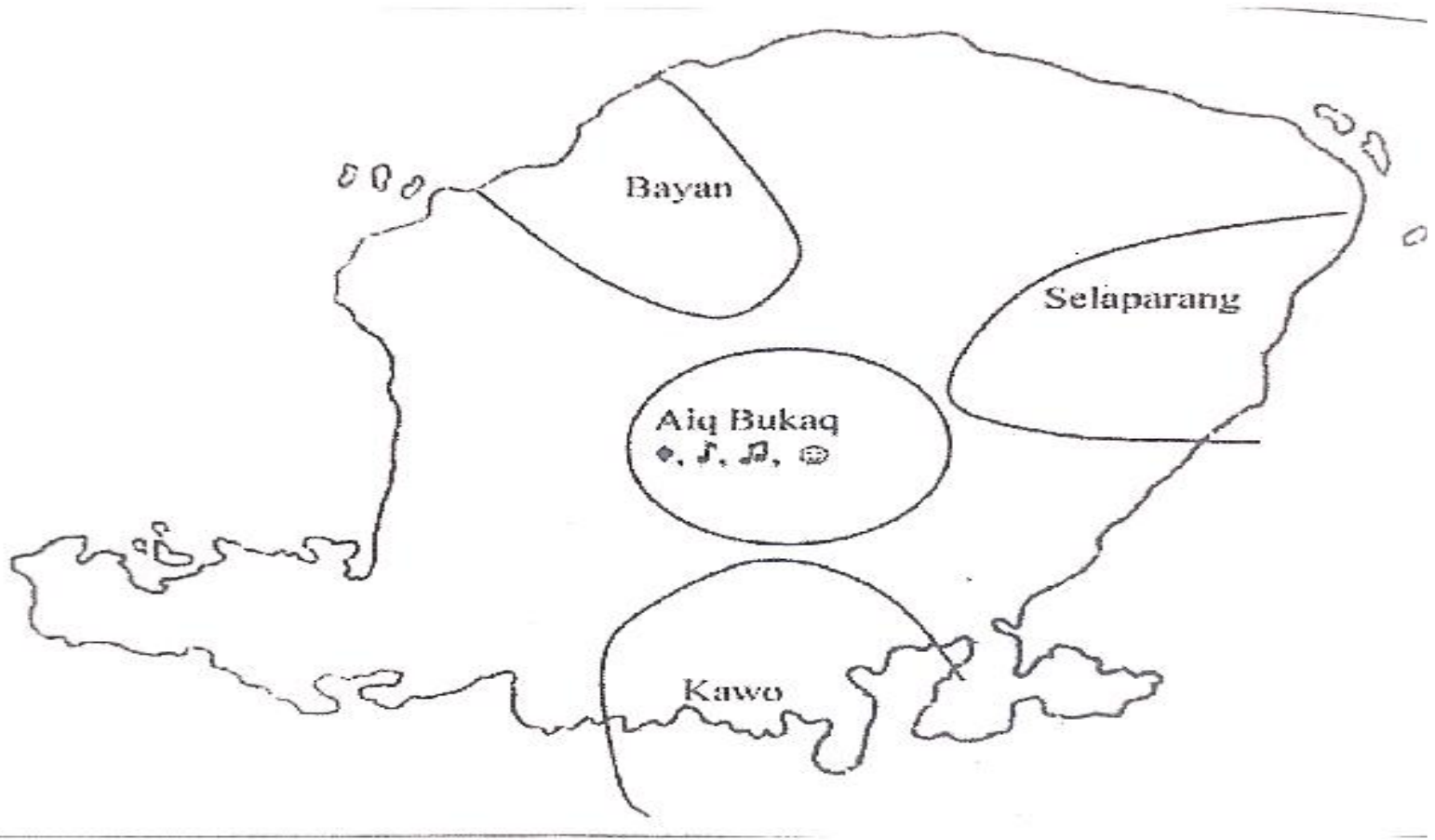


Mabasan, Vol. 1, No. 2, Juli-Desember 2007: 49-62

Keterangan : Pr/Dg\#(Raja Muhammad)

Pr/Dg\#(Sesigar)

Pr/Dg\#(Tuak Tuntel dait Tuak Tekedok

Pr/Lg\#(Batu Goloq)

Baca : - pada daerah terdapat karya sastra berbentuk prosa yang sejenis Dongeng dengan judul Raja

Muhamad

- pada daerah terdapat karya sastra berbentuk prosa yang berjenis Dongeng denngan judul

Sesiger

- Pada daerah terdapat karya Sastra berbentuk prosa yang berjenis Dongeng dengan judul Tuak Tuntel dait Tuak Tegodek

- Pada daerah terdapat karya Sastra berbentuk prosa yang berjenis legenda dengan judul Batu Golok)

\subsubsection{Cerita Rakyat Desa Kawo}

Di Desa Kawo, penulis lebih banyak menemukan cerita rakyat, yaitu 9 cerita dengan judul-judul sebagai berikut: 1) Klek dan kuwok, 2) Balang Kesimbar, 3) Terwek-wek, 4) Amaq Terompes, 5) Amet, 6) Rangga Dudang, 7) putri mandalika, 8) Datu pejanggik, 9) Gunung Pujut. Berdasarkan jenisnya, cerita rakyat berjudul 1) klek dan kuwok, 2) Balang Kesimbar, 3) Terwek-wek, 4 ) Amaq Terompes, adalah dongeng. Sedangkan cerita Rakyat berjudul 1) Amet, 2) Rangga Dundang, 3) putri mandalika, 4) Datu pejanggik, 5) Gunung Pujut adalah legenda. 
Tabel 3

Tabulasi Cerita Rakyat Desa Kawo

\begin{tabular}{|c|c|c|c|c|c|c|c|c|c|}
\hline No. & Judul & Bentuk & Waktu & Setting & tokoh & Alur & Dipercya & Sifat & Jenis \\
\hline 1 & $\begin{array}{l}\text { Klek dan } \\
\text { kowok }\end{array}$ & Prosa & Dahulu & $\begin{array}{l}\text { Dunia } \\
\text { sperti } \\
\text { sekarang } \\
\text { (hutan } \\
\text { pujut ) }\end{array}$ & $\begin{array}{l}\text { Manusia } \\
\text { (Klek dan } \\
\text { kuwok) }\end{array}$ & Maju & Fiksi & Sekuler & Dongeng \\
\hline 2 & $\begin{array}{l}\text { Balang } \\
\text { Kesimbar }\end{array}$ & Prosa & Dahulu & $\begin{array}{l}\text { Dunia } \\
\text { sperti } \\
\text { sekarang }\end{array}$ & $\begin{array}{l}\text { Manusia } \\
\text { (Balang } \\
\text { Kesimbar) } \\
\end{array}$ & Maju & Fakta & Sekuler & Dongeng \\
\hline 3 & $\begin{array}{l}\text { Terwek- } \\
\text { wek }\end{array}$ & Prosa & Dahulu & $\begin{array}{l}\text { Dunia } \\
\text { sperti } \\
\text { sekarang }\end{array}$ & $\begin{array}{l}\text { Manusia } \\
\text { (Terwek- } \\
\text { wek) }\end{array}$ & Maju & Fiksi & Sekuler & Dongeng \\
\hline 4 & $\begin{array}{l}\text { Amak } \\
\text { Terompes }\end{array}$ & Prosa & Dahulu & $\begin{array}{l}\text { Dunia } \\
\text { sperti } \\
\text { sekarang } \\
\text { (Sebuah } \\
\text { Hutan) }\end{array}$ & $\begin{array}{l}\text { Manusia } \\
\text { (Amaq } \\
\text { Terompes) }\end{array}$ & Maju & Fiksi & Sekuler & Dongeng \\
\hline 5 & Amet & Prosa & Dahulu & $\begin{array}{l}\text { Dunia } \\
\text { sperti } \\
\text { sekarang } \\
\text { (Zaman } \\
\text { Kerajaan) }\end{array}$ & $\begin{array}{l}\text { Manusia } \\
\text { (Amet) }\end{array}$ & Maju & Fakta & Sekuler & Legenda \\
\hline 6 & $\begin{array}{l}\text { Rangga } \\
\text { Dudang }\end{array}$ & Prosa & Dahulu & $\begin{array}{l}\text { Dunia } \\
\text { sperti } \\
\text { sekarang } \\
\text { (Zaman } \\
\text { Kerajaan) } \\
\end{array}$ & $\begin{array}{l}\text { Manusia } \\
\text { (Rangga } \\
\text { dudang) }\end{array}$ & Maju & Fakta & Sekuler & Legenda \\
\hline 7 & $\begin{array}{l}\text { Putri } \\
\text { Mandalika }\end{array}$ & Prosa & Dahulu & $\begin{array}{l}\text { Dunia } \\
\text { sperti } \\
\text { sekarang } \\
\text { (Zaman } \\
\text { Kerajaan } \\
\text { selaparang) }\end{array}$ & $\begin{array}{l}\text { Manusia } \\
\text { (Putri } \\
\text { Mandalika) }\end{array}$ & Maju & Fakta & Sekuler & Legenda \\
\hline 8 & $\begin{array}{l}\text { Datu } \\
\text { Pejanggik }\end{array}$ & Prosa & Dahulu & $\begin{array}{l}\text { Dunia } \\
\text { sperti } \\
\text { sekarang } \\
\text { (Zaman } \\
\text { Kerajaan) }\end{array}$ & $\begin{array}{l}\text { Manusia } \\
\text { (Datu } \\
\text { Pejanggik) }\end{array}$ & Maju & Fakta & Sekuler & Legenda \\
\hline 9 & $\begin{array}{l}\text { Gunung } \\
\text { Pujut }\end{array}$ & Prosa & Dahulu & $\begin{array}{l}\text { Dunia } \\
\text { sperti } \\
\text { sekarang } \\
\text { (Zaman } \\
\text { Kerajaan } \\
\text { Majapahit) }\end{array}$ & $\begin{array}{l}\text { Manusia } \\
\text { (Sri } \\
\text { Maharaja } \\
\text { Mulia) }\end{array}$ & Maju & Fakta & Sekuler & Legenda \\
\hline
\end{tabular}


Mabasan, Vol. 1, No. 2, Juli-Desember 2007: 49-62

Peta 3

Sebaran Cerita Rakyat Desa Kawo

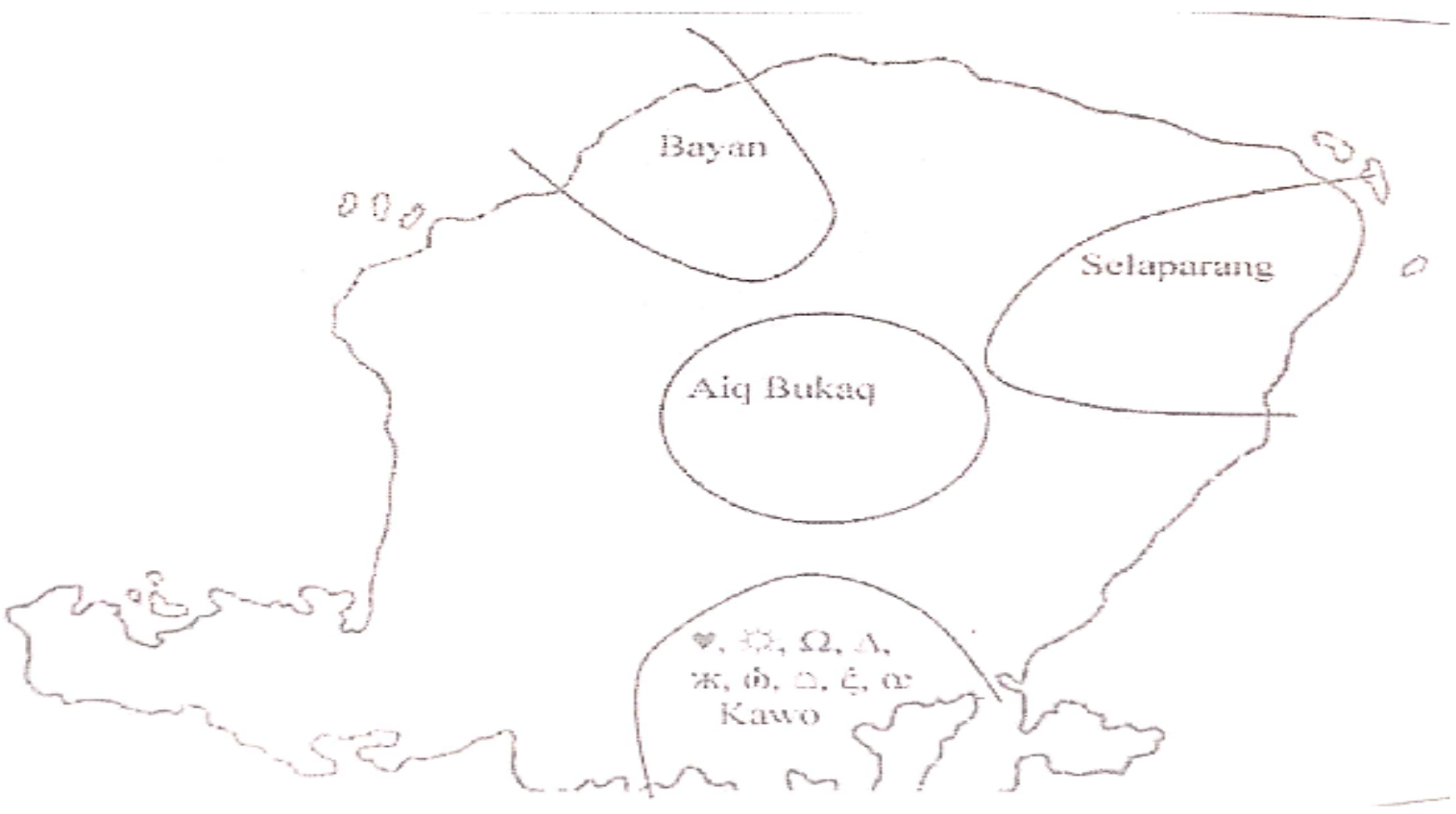

Scanned by CamScanner 
Keterangan :

: Pr/Lg\# (Putri Mandalika)

: Pr/Lg\# (Datu Pejanggik)

: Pr/Lg\# (Balang Kesimbar)

: Pr/Lg\# (Terwek-wek)

: Pr/Lg\# (Amak Terompes)

: Pr/Lg\# (Amet)

: Pr/Lg\# (RanggaDudang)

: Pr/Lg\#(Klek dan Kuwok)

: Pr/Lg\# (Gunung Pujut)

(Dibaca sama dengan peta sebaran cerita rakyat desa bayan, Aiq Bukaq, dst.)

\subsubsection{Cerita Rakyat Desa Selaparang}

Pada desa selaparang, penulis menemukan 4 cerita rakyat dengan judul-judul sebagi berikut, 1) Loq Dawit, 2) Patih Longgok Elong, 3) Datu Langko, 4) Doyan Neda.Berdasarkan jenisnya judul-judul tersebut adalah Legenda.

Tabel 4

Tabulasi Cerita Rakyat Desa Selaparang

\begin{tabular}{|l|l|l|l|l|l|l|l|l|l|}
\hline No. & Judul & Bentuk & Waktu & Setting & tokoh & Alur & Dipercya & Sifat & Jenis \\
\hline 1 & $\begin{array}{l}\text { Lok } \\
\text { Dawit }\end{array}$ & Prosa & Dahulu & $\begin{array}{l}\text { Dunia sperti } \\
\text { sekarang } \\
\text { (Zaman } \\
\text { Kerajaan } \\
\text { Selaparang } \\
\text { ) }\end{array}$ & $\begin{array}{l}\text { Manusia } \\
\text { (Lok Dawit) }\end{array}$ & Maju & Fakta & Sekuler & Legenda \\
\hline 2 & $\begin{array}{l}\text { Patih } \\
\text { Elonggak }\end{array}$ & Prosa & Dahulu & $\begin{array}{l}\text { Dunia sperti } \\
\text { sekarang } \\
\text { (Zaman } \\
\text { Kerajaan) }\end{array}$ & $\begin{array}{l}\text { Manusia } \\
\text { (Sinangling) }\end{array}$ & Maju & Fakta & Sekuler & Legenda \\
\hline 3 & $\begin{array}{l}\text { Datu } \\
\text { Langko }\end{array}$ & Prosa & Dahulu & $\begin{array}{l}\text { Dunia sperti } \\
\text { sekarang } \\
\text { (Zaman } \\
\text { Kerajaan) }\end{array}$ & $\begin{array}{l}\text { Manusia } \\
\text { (Raden Mas } \\
\text { Panjitilar) }\end{array}$ & Maju & Fakta & Sekuler & Legenda \\
\hline 4 & $\begin{array}{l}\text { Doyan } \\
\text { Neda }\end{array}$ & Prosa & Dahulu & $\begin{array}{l}\text { Dunia sperti } \\
\text { sekarang } \\
\text { (Zaman } \\
\text { Kerajaan } \\
\text { Selaparang) }\end{array}$ & $\begin{array}{l}\text { Manusia } \\
\text { (Doyan } \\
\text { Neda) }\end{array}$ & Maju & Fakta & Sekuler & Legenda \\
\hline
\end{tabular}




\section{Peta 4}

\section{Sebaran Cerita Rakyat Desa Selaparang}

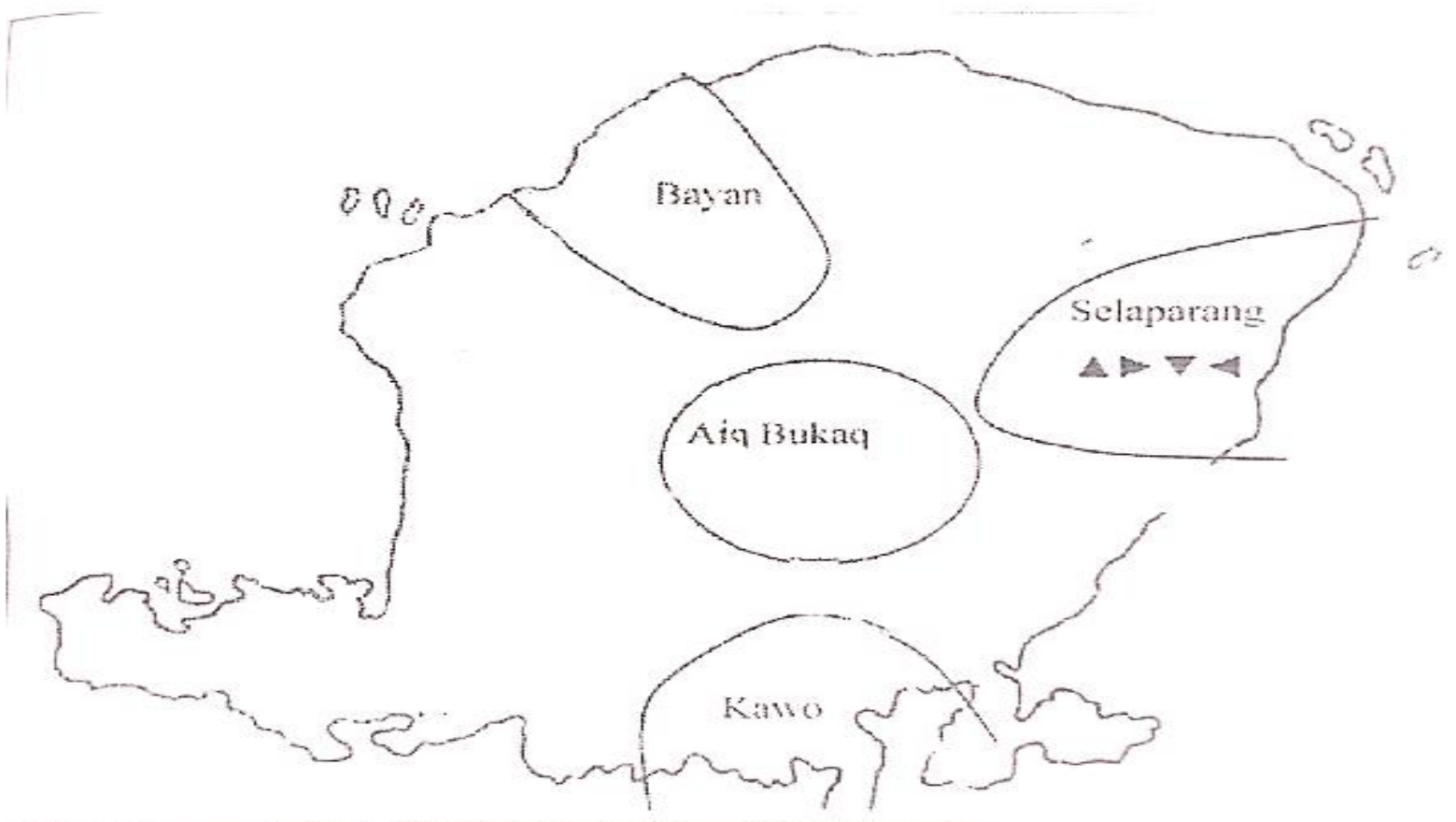

Scanned by CamScanner

Keterangan:

: Pr/Lg\# (Loq Dawit)

: Pr/Lg\# ( Patih Longgak Elong)

: Pr/Lg\# (Datu Loangko)

: Pr/Lg\# (Doyan Neda)

( Baca :- pada daerah terdapat karya sastra berbentuk Prosa yang berjenis Legenda dengan judul Loq Dawit

- pada daerah terdapat karya sastra berbentuk Prosa yang berjenis Legenda dengan judul Patih Longgak Elong 
- pada daerah terdapat karya sastra berbentuk Prosa yang berjenis Legenda dengan judulDatu Langko

- pada daerah terdapat karya sastra berbentuk Prosa yang berjenis Legenda dengan judul Doyan Neda

\section{Simpulan}

Kajian terhadap prosa rakyat Sasak di Lombok menghasilkan simpulan sebagai berikut. Peneliti berhasil mengumpulkan dan menemukan dua jenis sastra lisan masyarakat Sasak di pulau Lombok yang terdapat pada cerita Loq Dawit, Patih Longgak Elong, Datu Langko, Doyan Neda, Putri Mandalika, Datu Pejanggik, Rangga Dudang, Gunung Pujut, Terwekwek, Tuak Tuntel dait Tuak Tegodek, Batu Golok, Bibi Cili, Cupak Gerantang, Raja Muhamad, Sesogar, Amet, Balang Kesimbar, Amak Terompes, Klek dan Kluwok. Dari segi jenisnya cerita-cerita rakyat tersebut tersebut termasuk legenda dan dongeng.

Kesembilan belas cerita rakyat tersebut dapat ditabulasikan dalam jenis legenda dan dongeng menurut daerah pengamatan.

Table 5

Cerita Rakyat Sasak Jenis Legenda dan Dongeng Menurut Daerah Pengamatan

\begin{tabular}{|l|l|l|l|}
\hline No. & Judul & Jenis & Daerah Pengamatan \\
\hline 1. & Bibi Cili & Legenda & Desa Bayan \\
\hline 2. & Cupak Gerantang & Legenda & Desa Bayan \\
\hline 3. & Loq Dawit & Legenda & Desa selaparang \\
\hline 4. & Patih Longkok Elong & Legenda & Desa selaparang \\
\hline 5. & Datu Langko & Legenda & Desa selaparang \\
\hline 6. & Doyan Neda & Legenda & Desa selaparang \\
\hline 7. & Mandalika & Legenda & Desa Kawo \\
\hline
\end{tabular}


Mabasan, Vol. 1, No. 2, Juli-Desember 2007: 49-62

\section{DAFTAR PUSTAKA}

Dananjaya, James. 1991. Folkor Indonesia Ilmu Gosip, Dongeng, dan Lain-Lain. Jakarta: Graffiti

Hutomo, Suripan, Sadi. 1991. Mutiara Yang Terlupakan (Pengantar Studi Sastra Lisan). . Surabaya: HISKI.

Koentjaraningrat. 2002. Kebudayaan, Mentalis, dan Pembangunan. Jakarta: Gramedika.

Mahsun. 2005. Pemetaan Variasi Dialektikal Bahasa Sasak. Mataram: Kerjasama BAPPEDA Provinsi Nusa Tenggara Barat Dan Yayasan Bina Insani. 